\title{
Analisis Nilai-Nilai Pancasila yang Terkandung dalam Perilaku Bermain Anak Kelas V SDN Ardirejo 4 Kepanjen Kabupaten Malang
}

\author{
Imamuddin Mardhotillah Sabila* \\ Universitas Negeri Malang, Jl. Semarang No. 5 Malang, Jawa Timur, Indonesia \\ *Penulis korespondensi, Surel: abilms99@gmail.com
}

Paper received: 1-4-2021; revised: 22-4-2021; accepted: 29-4-2021

\begin{abstract}
Abstrak
Nilai-nilai Pancasila di Indonesia ditanamkan denan tujuan untuk menghasilkan peserta didik yang bertanggung jawab dalam menyelesaikan masalah demi kesejahteraan. Berdasarkan hasil pengamatan di salah satu sekolah dasar, diketahui bahwa jarang sekali ditemukan kurangnya penerapan nilai Pancasila saat bermain. Penelitian tertarik melaksanakan peelitian di SDN Ardirejo 4 Kepanjen Kabupaten Malang. Metode yang digunakan adalah kualitatif deskriptif. Secara keseluruhan penerapan nilai-nilai Pancasila pada perilaku bermain siswa kelas V SDN Ardirejo 4 Kepanjen Kabupaten Malang sudah cukup baik. Perlu adanya kerja sama yang baik antara sekolah, orang tua, dan pengondisian lingkungan yang baik serta pemberian fasilitas yang dapat mendukung penanaman nilai-nilai Pancasila pada perilaku bermain anak.
\end{abstract}

Kata kunci: nilai-nilai Pancasila; perilaku bermain; anak sekolah dasar

\section{Pendahuluan}

Pembelajaran nilai-nilai pancasila sejak usia sekolah dasar bertujuan untuk membiasakan adab dan etika yang baik sejak dini. Anak tumbuh dan berkembang dengan karakteristik dan sifat-sifatnya masing-masing, tetapi berbeda dengan sikap etika yang didapat anak dari apa yang dilihat dan diajarkan kepadanya setiap harinya. Dengan adanya nilai-nilai Pancasila, akan terwujud peserta didik yang mampu memecahkan masalah dalam kehidupan dengan penuh tanggung jawab. Peserta didik mampu beradaptasi dengan perubahan lingkungan termasuk IPTEK (Kaelan, 2014). Dari pendapat yang telah dipaparkan dapat disimpulkan bahwa anak usia dini disiapkan untuk mengatasi segala macam kondisi perubahan zaman yang terjadi dengan dimilikinya pedoman hidup yang baik sesuai hari nuraninya.

Perkembangan anak dapat mempengaruhi sikap anak dalam berperilaku yang disertai dengan perasaan tertentu saat berinteraksi dengan orang lain. Menurut Wiyani (2014) sikap anak saat bermain juga dipengaruhi oleh perkembangan sosial dan emosi. Dari pendapat di atas dapat di simpulkan bahwa anak usia dini akan memiliki perkembangan sikap dan karakter yang baik apabila lingkungan dan pola asuh yang baik. Lingkungan dan dunia anak usia dini tidaklah jauh dari bermain. Melalui kegiatan bermain, anak belajar banyak hal. Bermain merupakan bagian yang amat penting dalam tumbuh kembang anak untuk menjadi manusia seutuhnya.

Perilaku anak usia dini dalam bermain tidak lepas dari lingkungan sosialnya. Menurut Mutiah (2010) suatu kegiatan yang dapat digunakan sebagai tolak ukur atas potensi yang dimiliki anak melalui interaksi adalah permainan. Artinya, melalui bermain anak mulai berinterkasi dengan lingkungan sekitarnya. Pada usia anak tujuh tahun, kemampuan 
bersosialisasinya jauh lebih baik daripada masa awal kanak-kanak yang cenderung memunculkan otonimi daripada individualitas (Piaget \& Inhelder, 2016). Dilihat dari aspek sosial emosional, melalui kegiatan bermain anak dilatih untuk memahami adanya aturan main dan dituntut untuk mentaatinya. Anak dilatih untuk bersikap kooperatif dan menunjukkan antusiasme dalam melakukan permainan kompetitif secara positif.

Berdasarkan hasil pengamatan ketika melaksakan KPL di SDN Sumbersari 2 Kota Malang, dimana sekolah tersebut merupakan sekolah percontohan untuk sekolah inklusi. Peneliti menemukan fakta yang berbeda dari SD sebelumnya saat pelaksanaan magang. Hal yang mendasari penelitin tertarik melakukan penelitian ini adalah sikap bermain anak yang tidak membeda-bedakan teman yang menyandang inklusi. Siswa mampu memberikan rasa pengertian bahkan melindungi teman-temannya yang mempunyai kebutuhan khusus tersebut. Kegiatan bermain anak di sekolah tersebut jarang sekali ditemukan di sekolah lain yang notabene selalu meinggirkan teman yang berkebutuhan khusus dan dianggap mengganggu. Sikap toleransi, saling menghargai, dan tidak membeda-bedakan jarang sekali ditemukan pada anak usia sekolah dasar. Terbukti dengan tidak ditemukannya kejadian ini pada sekolah tempat peneliti magang sebelumnya. Sehingga peneliti tertarik untuk meneliti permasalahan ini di SDN Ardirejo 4 Kepanjen Kabupaten Malang. Lokasi tersebut dipilih karena peneliti banyak mengetahui perilaku siswa dalam kehidupan sehari-hari.

Penelitian Nurwardian (2019) menyatakan bahwa nilai-nilai Pancasila sudah termuat dalam buku siswa Kelas VI Tema 2. Nilai-nilai pancasila juga sudah diterapkan dengan baik pada kegiatan ekstrakulikuler karawitan dikarenakan nilai keagamaan yang juga diterapkan pada ekstrakulikuler tersebut (Fadhilah, 2019). Dari aspek perilaku bermain anak, penerapan nilai-nilai Pancasila tidak hanya melalui media board game, melainkan melihat perilaku bermain anak secara alami di lapangan (Oematan, dkk., 2020). Pada penelitian Kristiono, dkk (2019) juga dapat diketahui implementasi nilai-nilai Pancasila difokuskan pada perilaku bermain anak. Dapat diketahui bahwa implementasi nilai-nilai Pancasila sudah cukup baik di setiap sila-sila yang ada. Penelitian Wijaya (2015) mendapatkan hasil bahwa cara bermain anak identic berdasarkan gender. Pada penelitian ini, perilaku bermain anak ditinjau dari segi penerapan nilai-nilai Pancasila.

Berdasarkan beberapa permasalahan yang terdapat pada pengalaman, peneliti berkeinginan untuk menganalisis pada SD yang lain untuk menemukan apakah anak di sekolah dan daerah berbeda memiliki sikap yang mencerminkan nilai-nilai pancasila, maka dari itu peneliti tertarik untuk mengangkat judul "Analisis Nilai-Nilai Pancasila Yang Terkandung Dalam Perilaku Bermain Anak Kelas V SDN Ardirejo 4 Kepanjen Kabupaten Malang”.

\subsection{Nilai-Nilai Pancasila}

Pancasila sebagai dasar negara dan pedoman hidup seluruh warga negara Indonesia dalam menjalani kehidupan setiap harinya. Seluruh warga negara Indonesia wajib menghayati dan mengimani nilai-nilai luhur yang terdapat pada pancasila dalam kehidupan bermasyarakat,berbangsa dan bernegara (Adi, 2016). Nilai-nilai pancasila merupakan nilainilai luhur yang menjadi tolak ukur warga Indonesia dalam berperilaku. Tidak terkecuali bagi anak usia sekolah dasar dalam berperilaku. Perilaku anak usia dini pada umumnya tidak terlepas dari bermain, rasa ingin bermain anak pada umumnya lebih tinggi dari pada keinginannya dalam belajar. 
Nilai Ketuhanan Yang Maha Esa yang terdapat pada sila pertama yang merupakan sumber dari keempat sila yang lainnya. Pada usia sekolah dasar perilaku yang muncul dari anak yang melakukan interaksi kepada sesama teman ketika bermain. Nilai-nilai Pancasila sila pertama ini ditungkan dalam 7 butir.

Nilai kemanusiaan yang adil dan beradab menunjukkan bahwa manusia adalah mahluk sosial yang memasyarakat dan saling membutuhkan satu sama lain. Pada sikap bermain anak sikap kemanusiaan yang adil dan beradap dapat tercermin pada sikap adil dan tidak membedabedakan teman, rasa menghargai sesama seperti ucapat maaf dan terima kasih. Nilai-nilai Pancasila sila kedua ini ditungkan dalam 10 butir.

Nilai persatuan Indonesia salah satu sikap nasionalisme yang harus dimiliki oleh setiap warga negara Indonesia. Setiap anak memiliki karakter yang beragam begitu juga suku, ras dan budayanya, pada perilaku bermain anak kita dapat mengidentifikasi bagaimana anak memperlakukan teman bermainnya ketika terjadi perbedaan pendapat. Anak yang memiliki sikap persatuan Indonesia akan berusaha mencari titik temu agar tidak terjadi pertengkaran antar teman, sikap menghargai juga menjadi tolak ukur anak dalam menjaga kerukunan antar sesama. Nilai-nilai Pancasila sila ketiga ini ditungkan dalam 7 butir.

Nilai kerakyatan merupakan nilai yang mengedepankan kepentingan bersama daripada kepentingan pribadi. Pada perilaku bermain anak yang sering kita ketahui, banyak anak usia sekolah dasar yang bertengkar dengan teman nya hanya karena berbeda pendapat dan salah faham. Sila keempat dijabarkan dalam 10 butir.

Nilai keadilan merupakan dasar bagi seluruh rakyat Indonesia. Nilai keadilan ini dapat diterapkan pada perilaku bermain anak sekolah dasar sehari-hari, dimana dalam bermain anak harus bersikap adil dan tidak membeda-bedakan teman sepermainannya. Sila kelima dijabarkan dalam 11 butir.

\subsection{Perilaku Bermain Anak}

Perilaku merupakan suatu tindakan yang dilakukan sebagai suatu respon. Perilaku berfokus pada suatu cara untuk mencapai tujuan (Bashori, 2017). Suatu perilaku didorong oleh sebuah keinginan mendapatkan sesuatu yang dituju. Namun, keinginan tersebut seringkali tidak disadari oleh pelaku secara spesifik. Bermain merupakan kegiatan yang dilakukan tanpa ada unsur keterpaksaan sebagai suatu kegiatan yang menyenangkan dan lebih menekankan pada manfaat bagi seluruh aspek perkembangan anak (Pratiwi, 2017). Bermain tidak hanya suatu kegiatan yang menyenangkan akan tetapi merupakan kegiatan yang memiliki tujuan yaitu untuk mengoptimalkan seluruh aspek perkembangan anak. Bermain merupakan sarana bagi anak untuk mendapatkan pengetahuan tentang lingkungan dan sekitarnya. Sehingga dapat diketahui bahwa perilaku bermain merupakan suatu tindakan dalam kegiatan tanpa unsur paksaan dan menekankan pada upaya optimalisasi perkembangan anak.

Perilaku bermain memiliki manfaat bagi perkembangan anak. Simatupang (2005) menjelaskan bahwa bermain merupakan kegiatan yang erat kaitannya dengan gerak fisik. Dalam implementasinya, bermain mencakup aktualisasi potensi, sikap dan perilaku anak. Melalui kegiatan bermain, anak akan mendapatkan hal-hal positif berupa kepuasan, kesenangan dan penyaluran kelebihan energi. Berdasarkan karakteristik kognitif, sosial, emosi, dan fisik, siswa sekolah dasar memiliki keunikan. Usia sekolah dasar seringkali 
diidentikkan dengan banyak bertingkah, kelebihan gerak, dan nakal dalam hubungan sosialnya (Mahabbati, 2006). Dalam koridor tertentu perilaku-perilaku tersebut masih dapat ditolerir sebagai manifestasi dari usia mereka.

\subsection{Perilaku Sesuai Pancasila}

Anak pada usia dini merupakan masa keemasan bagi anak untuk tumbuh, berkembang dan menyerap segala informasi yang ada di sekitarnya. Faktor-faktor yang didapat dari lingkungan anak itulah yang mempengaruhi sikap anak dalam bersikap. Menurut Mutiah (2010) kehidupan pada masa anak beragai pengaruhnya merupakan masa kehidupan yang sangat penting khususnya berkaitan dengan diterimanya rangsangan (stimulasi) dan perlakuan dari lingkungan hidupnya. Oleh sebab itu pada periode sensitif dimana kualitas perangsangan harus diatur dengan sebaik-baiknya. Merurut Mahabbati (2006) anak usia sekolah dasar seringkali di golongkan sebagai banyak tingkah, kelebihan gerak, dan nakal dalam hubungan sosialnya. Proses sikap yang telah diserap anak dalam bersikap dapat tercermin pada saat anak berkegiatan tak terkecuali dalam bermain, sudah menjadi hal yang wajar jika anak cenderung lebih suka bermain. Dalam bermain anak berinteraksi dengan objek dan individu lain di sekitarnya, dalam interaksi tersebut akan nampak skap-sikap anak yang baik dan mencerminkan nilai-nilai pancasila atau sebaliknya yang bertentangan dengan nilainilai Pancasila.

\section{Metode}

Pada penelitian ini menggunakan pendekatan kualitatif. Jenis penelitian yang digunakan dalam penelitian ini adalah metode diskriptif. Pada penelitian kualitatif peneliti mengamati kegiatan siswa secara intens pada kegiatan yang sedang dilaksanakan melalui observasi, wawancara dan dokumentasi mengenai nilai-nilai pancasila yang terdapat dalam perilaku bermain anak kelas V SDN Ardirejo Kepanjen Kabupaten Malang. Penelitian akan dilaksanakan selama 14 hari. Pengambilan data akan di laksanakan pada jam bermain siswa setelah kegiatan BDR (Belajar Dari Rumah) di rumah siswa masing-masing dan 4 kali penelitian akan di laksanakan ketika siswa bermain bersama. Penelitian ini didukung instrumen penunjang berupa pedoman observasi dan pedoman wawancara. Kisi-kisi instrumen observasi diadaptasi dari butir-butir Pancasila dan pengembangan indikatornya. Sedangkan kisi-kisi instrument wawancara dirancang berdasarkan kebutuhan di lapangan.

\section{Hasil dan Pembahasan}

\subsection{Penerapan Nilai-Nilai Pancasila Sila Ke-1}

Penerapan sila ke-1 Pancasila pada perilaku bermain anak kelas V merupakan suatu bentuk internalisasi nilai spiritual yang menjadikan siswa sadar bahwa kehidupan adalah anugerah dari Tuhan Yang Maha Esa. Dengan adanya kesadaran ini, siswa akan selalu mengingat Tuhannya dalam melaksanakan kegiatan sehari-hari termasuk bermain. Menurut Sulianti dkk (2020:63) dalam kehidupan bermasyarakat nilai religious terlihat mudah namun sulit dalam penerapan nya. Oleh sebab itu agama menjadi patokan untuk membentuk karakter moral bangsa yang lebih baik.

Dalam perilaku bermain anak kelas V, nilai-nilai Pancasila sila ke-1 diterapkan oleh siswa ketika masuk waktu solat bagi siswa muslim. Siswa menyadari bahwa kemampuan membaca Al Quran merupakan bentuk hubungan manusia dengan Tuhannya. Siswa bersikap 
menjauhi perilaku merendahkan teman yang tidak bisa membaca Al Quran saat bermain sebagai bentuk toleransi inter pemeluk agama yang sama. Siswa tetap menunjukkan kerja sama yang baik dalam bermain meskipun terdapat keragaman kemampuan membaca $\mathrm{Al}$ Quran. Siswa membina kerukunan hidup di antara sesama umat beragama. Jika ada teman yang berbeda agama, maka siswa tidak membeda-bedakan saat bermain. Siswa juga mempersilahkan temannya untuk beribadah dan tidak mengganggu. Sehingga dapat diketahui bahwa penerapan nilai-nilai Pancasila sila ke-1 pada perilaku bermain anak kelas V SDN Ardirejo 4 sudah diterapkan. Hal ini dapat diketahui dari adanya perilaku siswa yang menunjukkan penerapan butir Pancasila A2, A3, dan A4.

Pihak sekolah telah menerapkan pembiasaan KI 1 dengan menghafal surat-surat pendek bersama pada hari tertentu. Sedangkan pada jam istirahat siang, siswa melaksanakan solat dzuhur berjamaah. Upaya ini dinilai efektif untuk mengondisikan siswa dalam menerapkan nilai-nilai Pancasila khususnya sila ke-1. Orang tua siswa berperan dalam menanamkan nilai-nilai Pancasila sila ke-1 saat siswa di ligkungan rumah. Orang tua peduli akan kemampuan siswa dalam hal membaca Al Quran. Sehingga orang tua memiliki inisatif untuk memberikan pendidikan non formal seperti TPQ. Selain itu, orang tua juga memantau pelaksanaan solat 5 waktu. Pemantuan ini sebagai bentuk kepedulian dan kerja sama orang tua dengan sekolah.

\subsection{Penerapan Nilai-Nilai Pancasila Sila Ke-2}

Penerapan sila ke-2 Pancasila pada perilaku bermain anak kelas V merupakan suatu bentuk sikap dimana kita menghargai sesama selayaknya kita ingin di perlakukan baik oleh orang lain. Internalisasi dari nilai kemanusiaan dlam kehidupan sehari-hari berpacu di dalam 10 butir nilai-nilai Pancasila. Nilai kemanusiaan yang adil juga menganduk suatu makna di mana sebagainmahluk yang beradab dan berbudaya manusia haruslah bertindak adil, dalam hal ini manusia harus berperilaku adil terhadap dirinya sendiri, adil terhadap sesame manusia, adil terhadap lingkungan, dan adil terhadap Tuhan Yang Maha Esa (Umam, 2018)

Dalam perilaku bermain anak kelas V, nilai-nilai pancasila sila ke-2 di terapkan oleh siswa dengan menunjukkan rasa kepeduliannya terhadap apa yang terjadi di lingkungan sekitarnya. Selain itu rasa kemanusiaan siswa juga ditunjukkan dengan cara mereka memperlakukan teman bermainnya dengan tidak berbicara kasar serta menyakiti temannya. Siswa pun menyadari bahwa manusia memiliki kewajiban dan hak yang sama tanpa membedabedakan agama,suku, jenis kelamin dan lain sebagainya.

Siswa terbiasa mengamalkan nilai nilai kemanusiaan yang adil dan beradab. Dengan memberikan hukuman tegas terhadap siswa yang menyakiti adek kelas atau sesama temannya. Guru memberikan sanksi terhadap perilaku siswa yang tidak baik juga dengan memberikan Hukuman yang mendidik siswa, selain itu siswa di minta untuk meminta maaf serta berjanji untuk tidak melakukannya lagi. Hal seperti itu yang membuat siswa selalu teringat tentang apa yang selalu di ajarkan oleh guru mereka agar selalu berbuat baik terhadap sesama. Sehingga dapat diketahui bahwa penerapan nilai-nilai Pancasila sila ke-2 pada perilaku bermain anak kelas V SDN Ardirejo 4 sudah diterapkan. Hal ini dapat diketahui bahwa penerapan nilai-nilai Pancasila sila ke-2 pada perilaku bermain anak kelas V SDN Ardirejo 4 sudah diterapkan. Hal ini dapat diketahui dari adanya perilaku siswa yang menunjukkan penerapan butir Pancasila B1, B2, B3, B4, B5, B6, B7, B8, dan B9. 


\subsection{Penerapan Nilai-Nilai Pancasila Sila Ke-3}

Penerapan sila ke-3 Pancasila pada perilaku bermain anak kelas V Nilai-nilai persatuan merupakan landasan terbentuknya negara kesatuan Indonesia, dengan adanya persatuan rakyat Indonesia dapat keluar dari belenggu penjajahan. Menurut Kaelan (2014) kodrat manusia adalah sebagai mahluk sosial dan negara aalah kumpulan dari suatu elemenelemen yang berupa suku, ras, golongan maupun agama hal tersebut yang menjadikan pada suatu negara beraneka ragam tetapi tetep satu. Oleh sebab itu pentingnya persatuan dimana di Indonesia yang terdiri dari berbagai macam suku, ras dan agama apabila terjadi permusuhan maka akan terpecah belah. Nilai-nilai persatuan siswa dapat berpacu pada nilai-nilai persatuan yang tertuang pada 7 butir nilai-nilai Pancasila.

Dalam perilaku bermain anak kelas V, nilai-nilai pancasila sila ke-3 di terapkan oleh siswa pada saat mereka merasa bahwa melaksanakan kegiatan pada hari-hari besar kenegaraan merupakan suatu kebanggan, dan siswapun merasa tidak keberatan apabila sekolah menugaskan untuk melakukan upacara dan kegiatan-kegiatan lain. Penerapan nilainilai persatuan tercermin ketika siswa bermain adalah ketika siswa bermain maka mereka tidak membeda-bedakan temannya. Siswa perempuan yang mengikuti permainan sepakbola dengan teman laki-lakinya mennjukkan bahwa teman laki-laki menerima dengan senang hati. Dan ketika sepulang bermain pun terlihat siswa saling peduli dengan menunggu teman lain untuk pulang bersama. Sehingga dapat diketahui bahwa penerapan nilai-nilai Pancasila sila ke3 pada perilaku bermain anak kelas V SDN Ardirejo 4 sudah di terapkan. Hal ini dapat di ketahui dari adanya perilaku siswa yang menunjjukan penerapan butir Pancasila C1, C2, C3, C6, dan C7.

\subsection{Penerapan Nilai-Nilai Pancasila Sila Ke-4}

Penerapan sila ke-4 Pancasila pada perilaku bermain anak kelas V merupakan suatu bentuk cara siswa mengontro antara hak dan kewajiban siswa sebagai warga negara dalam menyampaikan pendapat dan menghargai pendapat orang lain. Siswa di ajarkan bagaimana cara menghargai perbedaan yang pada dasarnya perbedaan itulah yang dapat membuat hidup terasa lebih indah dan tidak membosankan Rube'i (2018). Nilai-nilai demokrasi siswa dapat berpacu pada nilai-nilai demokrasi yang tertuang dalam 10 butir nilai-nilai Pancasila.

Dalam perilaku bermain anak kelas V, nilai-nilai pancasila sila ke-4 di terapkan oleh siswa pada saat mereka terjadi perbedaan pendapat ketika bermain. Siswa yang memiliki rasa toleransi yang baik akan merasa bahwa kepentingan bersamalah lebih penting daripada keinginan pribadinya, selain itu rasa nilai demoklasi harus di dasari dengan rasa toleransi dalm berpendapat terhadap perbedaan suku budaya bahasa dan lain sebagainya. Penerapan nilai-nilai demokrasi ketika siswa bermain tercermin dari perilaku siswa yang mementingkan kepentingan bersama dan memilih untuk mengalah untuk mencegah perselisihan antar teman. Tidak hanya di lingkungan bermain dengan sebaya siswa yang mengamalkan nilai toleransi dalam berpendapat juga akan nampak lebih mengalah ketika siswa bermain dengan saudaranya di rumah walaupun mereka merasa bahwa pendapatnya benar. Sehingga dapat diketahui bahwa penerapan nilai-nilai Pancasila sila ke-4 pada perilaku bermain anak kelas $\mathrm{V}$ SDN Ardirejo 4 sudah diterapkan. Hal ini dapat diketahui dari adanya perilaku siswa yang menunjukkan penerapan butir Pancasila D1, D2, D3, D4, D5, D6, D7, D8, D9 dan D10. 


\subsection{Penerapan Nilai-Nilai Pancasila Sila Ke-5}

Penerapan sila ke-5 Pancasila pada perilaku bermain anak kelas V merupakan suatu bentuk sikap keadilan dan kemakmuran yang menjadi hak setiap warga negara Indonesia. Menurut Surip dkk (2016: 324) menjelaskan bahwa nilai keadilan sosial mengandung makna sebagai dasar dan tujuan untuk tercapainya ke adilan dan kemakmuran seluruh rakyat Indonesia secara lahiriah dan batiniah. Terlaksananya hukum yang adil dan kesejahteraan sandang, pangan, papan dan rasa keamanan merupakan bentuk kesejahteraan lahir dan batin dari rakyat Indonesia. Internalisasi dari nilai kemanusiaan dlam kehidupan sehari-hari berpacu di dalam 10 butir nilai-nilai Pancasila.

Dalam perilaku bermain anak kelas $\mathrm{V}$, nilai-nilai pancasila sila ke-5 di terapkan oleh siswa dengan melaksanakan kewajiban mereka dengan penuh tanggung jawab, siswa yang mengamalkan nilai keadilan tidak akan meminta haknya di dahulukan sebelum siswa menyelesaikan kewajibannya terlebih dahulu. Adapun di lingkungan bermain siswa menunjukkan nilai keadilan dengan selalu bertindak adil dan tidak membeda-bedakan temannya. Penerapan nilai-nilai keadilan ketika siswa bermain tercermin Ketika siswa tidak pernah membeda-bedakan jenis kelamin teman Ketika bermain di lingkungan sekitarnya. Siswa juga tidak pernah menggolongkan dirinya di suatu kubu yang mereka anggap paling cocok dengan dirinya. Dengan demikian mereka bisa bermain dengan tidak keterbatasan jenis permainan. Siswa yang menanankan nilai keadilan juga tercermin ketika mereka akan memilih bermain secara sportif walaupun pada akhirnya kalah. Sehingga dapat diketahui bahwa penerapan nilai-nilai Pancasila sila ke-5 pada perilaku bermain anak kelas V SDN Ardirejo 4 sudah diterapkan. Hal ini dapat diketahui bahwa penerapan nilai-nilai Pancasila sila ke-4 pada perilaku bermain anak kelas V SDN Ardirejo 4 sudah diterapkan. Hal ini dapat diketahui dari adanya perilaku siswa yang menunjukkan penerapan butir Pancasila E2, E3, E5, dan E7.

\subsection{Peran Guru, Orang Tua, dan Lingkungan dalam Penerapan Nilai-Nilai Pancasila}

Pancasila yang sejak dahulu diposisikan sebagai dasar negara dan dijadikan pedoman hidup bangsa seharusnya sudah terpatri di hati setiap insan. Namun kondisi yang terjadi saat ini berbeda jauh dengan apa yang telah dicita-citakan dalam Pancasila. Era digital ini menjadi tantangan tersendiri untuk penanaman nilai-nilai. Penguatan serta sinergitas tri sentra pendidikan sangat strategis untuk menumbuhkembangkan nilai-nilai Pancasila. Nilai-nilai Pancasila perlu diinternalisasikan termasuk dalam hal bermain. Hal ini tak akan terlaksana jika sepenuhnya diserahkan pada pihak sekolah, mengingat anak menghabiskan sebagian besar waktunya di rumah (Arriani, 2019). Sehingga dalam hal ini, peran orang tua sangat penting dalam menanamkan nilai-nilai Pancasila terutama selama masa pandemic yang mana siswa menghabiskan waktunya bersama orang tua dan keluarga di rumah.

Guru memiliki peran penting dan strategis bagi setiap pembaharuan pendidikan, hal ini yang menuntut guru untuk memiliki cara bertindak untuk menanamkan nilai-nilai Pancasila. Seorang guru harus menjadi seorang pengasuh bagi peserta didik, menjadi panutan dan teladan untuk dicontoh oleh peserta didik, guru pula harus menjadi pembimbing untuk membimbing anak didiknya yang memiliki integritas dan kedisiplanan dalam kehidupan sehari-hari. Namun upaya penanaman nilai-nilai Pancasila pada anak merupakan hal yang tidak mudah dijalankan oleh seorang guru. Guru akan kesulitan dalam membentuk karakter 
anak, jika tidak ada dukungan dari keluarga dan masyarakat yang ada di lingkungan peserta didik (Afif, 2018).

Lingkungan tempat tinggal anak di rumah kurang mendukung dan kurang membimbing serta kurang memberikan contoh yang baik tentu penanaman nilai-nilai Pancasila sulit diterapkan. Tentu hal ini akan berpengaruh pada anak berkaitan dengan keberhasilan penanaman nilai-nilai Pancasila. Lingkungan sekolah dan masyarakat sekitar memberikan dukungan penuh pada sekolah yang menerapkan nilai pancasila dalam kesehariannya. Warga sekolah terutama guru memaksimalkan lingkungan yang ada dalam menerapkan nilai-nilai Pancasila seperti melestarikan kegiatan yang positif, mengenalkan dan mempraktekkan permainan tradisional di saat prosese pembelajaran berlangsung yang sesuai dengan materi dan saat berolah raga. (Khosiah, 2020). Dengan masing masing peran yang dilakukan dengan baik oleh keluarga, sekolah maupun masyarakat dalam pendidikan, yang saling memperkuat dan saling melengkapi antara ketiga pusat itu, akan memberi peluang besar mewujudkan sumber daya manusia terdidik yang bermutu.

\section{Simpulan}

Berdasarkan rumusan masalah, hasil penelitian, dan pembahasan, dapat ditarik kesimpulan atas penerapan nilai-nilai Pancasila pada perilaku bermain siswa kelas V SDN Ardirejo 4 Kepanjen Kabupaten Malang sudah cukup baik. Penerapan nilai-nilai Pancasila sila ke-1 nampak pada butir Pancasila A2, A3, da A4. Penerapan nilai-nilai Pancasila sila ke-2 nampak pada butir Pancasila B1, B2, B3, B4, B5, B6, B7, B8, dan B9. Penerapan nilai-nilai Pancasila sila ke-3 nampak pada butir Pancasila C1, C2, C3, C6, dan C7. Penerapan nilai-nilai Pancasila sila ke-4 nampak pada butir Pancasila D1, D2, D3, D4, D5, D6, D7, D8, D9 dan D10. Penerapan nilai-nilai Pancasila sila ke-5 nampak pada butir Pancasila E2,E3, E5, dan E7. Perlu dikembangkan lagi untuk butir-butir Pancasila yang belum nampak secara keseluruhan.

\section{Daftar Rujukan}

Adi, P. (2016). Pembudayaan nilai-nilai Pancasila bagi masyarakat sebagai modal dasar pertahanan nasional NKRI. Jurnal Moral Kemasyarakatan, 1(1), 37-50.

Anggara, A. F. (2018). Strategi Guru Pendidikan Pancasila Dan Kewarganegaraan Dalam Pengembangan Wawasan Global Peserta Didik Berdasarkan Nilai-Nilai Pancasila. E-CIVICS, 7(2), 174-182.

Arriani, F. (2019). Orang Tua Sebagai Penanam Nilai Pancasila Untuk Anak Usia Dini Di Era Digital. JECE (Journal of Early Childhood Education), 1 (2), 60-68.

Bashori, K. (2017). Menyemai Perilaku Prososial Di Sekolah. SUKMA: Jurnal Pendidikan, 1(1)

Fadhilah, A. E. (2019). Nilai-Nilai Pancasila Pada Ekstrakurikuler Karawitan di SDN Sumbersari 1 Kecamatan Lowokwaru Kota Malang. Skripsi tidak diterbitkan. Malang: FIP UM.

Kaelan, M. S. (2014). Pendidikan Pancasila. Yogyakarta: Paradigma.

Khosiah, N. (2020). Implementasi Nilai-Nilai Pancasila Peserta Didik Di Madrasah Ibtidaiyah Mambail Falah Tongas-Probolinggo. Jurnal Al-Insyiroh: Jurnal Studi Keislaman, 6(1).

Kristiono, N., Wiratomo, G. H., \& Alfira, H. N. (2019). Implementasi Nilai-Nilai Pancasila Dalam Kegiatan Kepramukaan. Harmony, 4(1), 13-18.

Mahabbati, A. 2006. Identifikasi Anak dengan Gangguan Emosi dan Perilaku di Sekolah Dasar. Jurnal Pendidikan Khusus (JPK), 2(2): 4.

Mutiah, D. (2010). Psikologi Bermain Anak Usia Dini. Jakarta: Kencana Prenada Media Group.

Nurwardian, Y. L. (2019). Analisis Niliai Nilai Pancasila Pada Buku Siswa Kelas VI Tema 2 "Persatuan Dalam Perbedaan" Edisi Revisi 2018. Skripsi tidak diterbitkan. Malang: FIP UM. 
Oematan, V. N. C., Tanudjaja, B. B., Salamoon, D. K. (2020). Pengamalan Nilai-Nilai Pancasila Melalui Media Board Game Untuk Anak Usia 6-8 Tahun. Jurnal DKV Adiwarna, 1(16).

Piaget, J. \& Inhelder, B. (2016). Psikologi Anak. Yogyakarta: Pustaka Pelajar.

Pratiwi, W. (2017). Konsep bermain pada anak usia dini. TADBIR: Jurnal Manajemen Pendidikan Islam, 5(2), 106-117.

Rube'i, M. A. (2019). Implementasi Sila Kerakyatan yang Dipimpin oleh Hikmat Kebijaksanaan dalam Permusyawaratan Perwakilan pada Mahasiswa Program Studi PPKn Ikip PGRI Pontianak. Jurnal Pendidikan Kewarganegaraan, 2(2).

Simatupang, N. (2005). Bermain sebagai upaya dini menanamkan aspek sosial bagi siswa sekolah dasar. Jurnal Pendidikan Jasmani Indonesia, 3(1).

Efendi, Y., \& Sa'diyah, H. (2020). Penerapan Nilai-Nilai Pancasila Dalam Lembaga Pendidikan. JPK (Jurnal Pancasila dan Kewarganegaraan), 5(1), 54-65.

Surip, N. (2016). Pancasila dalam Makna dan Aktualisasi. Yogyakarta: Andi.

Umam, A. N. (2018). Implementasi Sila Kemanusiaan yang Adil dan Beradab di Sekolah Inklusi SMK Daruttaqwa Suci Manyar Gresik. Kajian Moral dan Kewarganegaraan, 6(2).

Wijaya, F. N. (2015). Persepsi Orang Tua Terhadap Perilaku Bermain Anak Berdasarkan Gender. S1 Thesis, Universitas Pendidikan Indonesia. (Online), (http://repository.upi.edu/22889/)

Wiyani, N. A. (2014). Psikologi Perkembangan Anak Usia Dini. Yogyakarta: Gava Media. 